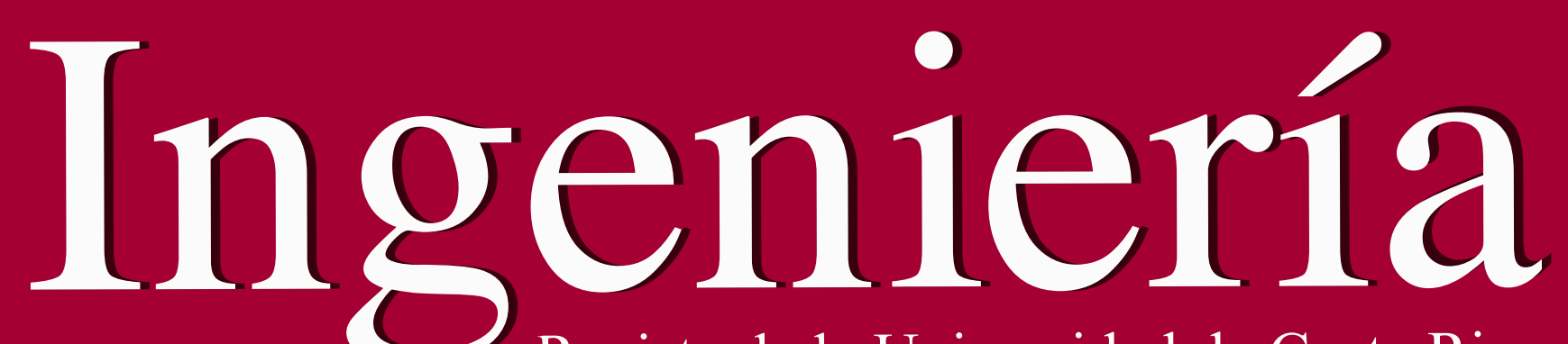

Revista de la Universidad de Costa Rica JULIO / DICIEMBRE 2020 - VOLUMEN 30 (2)

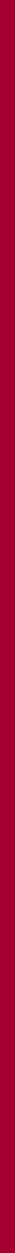




\title{
Aircraft Noise and Land Use Zoning Compatibility around the Juan Santamaría Airport, Costa Rica
}

\section{Compatibilidad del ruido aeronáutico y zonificación del uso de suelo alrededor del aeropuerto Juan Santa María, Costa Rica}

\author{
Ing. José M. Rivera Acevedo, \\ Civil Engineer, \\ University of Costa Rica, San José, Costa Rica \\ josemra7@gmail.com \\ ORCID: https://orcid.org/0000-0001-6327-2132 \\ Ing. Jonathan Agüero Valverde, Ph.D., \\ School of Civil Engineering, \\ University of Costa Rica, San José, Costa Rica \\ jonathan.aguero@ucr.ac.cr \\ ORCID: https://orcid.org/0000-0002-9096-9274
}

Recibido: 21 de junio 2019

Aceptado: 14 de febrero 2020

\begin{abstract}
The purpose of this study is to evaluate the noise generated by aeronautical operations around Juan Santamaría Airport and its compatibility with the land use and the proposed zoning around the airport. Aircraft noise can produce discomfort, interference with daily activities, and excessive vibrations; hence, land use planning around airports is of importance. Maps were prepared through computational models representing the noise levels generated by the operations of the airport. The operations were analyzed by aircraft type, schedules, and flight tracks for 2013 and projections for 2016, 2026, and 2036. Noise level data were collected with a sound level meter at 28 points surrounding the airport. Comparing the annual maps of 2013 and 2036, it was determined that $41,24 \%$ of the analyzed area will present clear perceivable increases $(5 \mathrm{~dB}$ to $10 \mathrm{~dB})$, and $1,36 \%$ of the area will have double loudness increases ( $10 \mathrm{~dB}$ to $14 \mathrm{~dB})$. The 2016 maps show locations where it is recommended to incorporate solutions in the construction regulation that reduce noise between $25 \mathrm{~dB}$ and $30 \mathrm{~dB}$ in the residential and scholar areas located within $65 \mathrm{~dB}$ and $70 \mathrm{~dB}$, such as Coco, Rincón Monge, Rincón Herrera, and Bajo Sorda. This finding is supported by field measurements. The proposed zoning was contrasted against the yearly day-night average sound level of 2036. The biggest issue of excessive aircraft noise is located near the west runway where a range above the $75 \mathrm{~dB}$ is expected. Any edification of permanent residence here must be banned.
\end{abstract}

Keywords:

Noise contours; development; maps; planning; urban 


\section{Resumen}

El propósito del estudio es evaluar el ruido generado por las operaciones aeronáuticas alrededor del Aeropuerto Juan Santamaría y su compatibilidad con el uso del suelo y zonificación propuesta alrededor del mismo. El ruido de aeronaves puede producir incomodidad, interferencia con actividades cotidianas y vibraciones excesivas, razón por la cual la planificación del uso del suelo alrededor de los aeropuertos es importante. Los mapas se elaboraron con modelos computacionales, representando niveles de ruido generados por las operaciones. Estas se analizaron por tipo de aeronave, horario y patrones de vuelo para 2013 y proyecciones para 2016, 2026 y 2036. Se recopilaron datos de nivel de ruido con un sonómetro en 28 puntos alrededor del aeropuerto. Comparando los mapas anuales de 2013 y 2036, se determinó que el 41,24\% del área analizada presentará aumentos claramente perceptibles ( $5 \mathrm{~dB}$ a $10 \mathrm{~dB})$ y el 1,36\% tendrá aumentos de sonoridad duplicada (10 dB a $14 \mathrm{~dB})$. Los mapas de 2016 muestran ubicaciones donde se recomienda incorporar soluciones al reglamento de construcción que reduzcan (25 a 30) dB en las áreas residenciales y escolares ubicadas entre (65 y 70) dB como Coco, Rincón Monge, Rincón Herrera, y Bajo Sorda. Este hallazgo está respaldado por mediciones en campo. La zonificación propuesta se contrastó con el nivel de sonido promedio anual de día-noche de 2036. El mayor problema del ruido de las aeronaves se encuentra cerca de la cabecera oeste, donde se esperan valores superiores a los $75 \mathrm{~dB}$. Cualquier edificación residencial permanente debe ser prohibida aquí.

\section{Palabras clave:}

Contornos de ruido; desarrollo; mapas; planificación; urbana 


\section{INTRODUCTION}

Among the most important effects of aircraft noise, one can include discomfort, interference with activities (conversations and sleep interference) and learning (especially in children), and vibrations induced by noise (Eagan, 2007). In residential areas, it is reported that sound levels greater than 55 $\mathrm{dB}$ cause interference in daily activities (Berglund, Lindvall \& Schwela, 1999), and at night, sleep can be interrupted by sound levels higher than $40 \mathrm{~dB}$ (World Health Organization, 2009). Studies also show that long-term exposure to aircraft noise is significantly associated with chronic noise stress, which causes the prevalence of hypertension (Black et al., 2007).

The impact generated by aeronautical noise goes beyond the health aspect and is also reflected in the lower value of the property costs (Hsu \& Lin, 2005). For example, Püschel and Evangelinos (2012) estimated that around the International Airport of Düsseldorf there was a decrease of $1.04 \%$ in the rent for each decibel of increased noise because of aeronautical operations. The Transportation Research Board (2008) stated that for the lands located in the proximity of airports, sleep interruption is also a factor that determines its cost among other factors such as the number of rooms, the scholastic facilities, and crime rates. Analyses such as the one performed in the highly urbanized vicinity of the Amsterdam airport determined that a reduction in $1 \mathrm{~dB}$ could provide a marginal benefit of 1,459 euros per house, equivalent to a total benefit of 574 million euros for all the study area (Dekkers \& van der Straaten, 2009). This study gives an idea, in monetary terms, of the negative effect that high noise levels from airport operations could generate.

According to Xie, Li and Kang (2014), the adverse effects of being exposed for long periods to the sound influence of aircrafts makes evident the need for developing the expansion of airports together with an adequate planning of residential areas. In the case of Costa Rica, the lack of field verifications of the noise levels generated by aeronautical operations reflects the scarce treatment given to this problem despite being a country where the development of the aviation is important, counting with four international airports and more than 100 aerodromes of mainly local use (Ministry of Public Works and Transportation from Costa Rica- General Civil Aviation Authority, 2014). The Juan Santamaría International Airport (JSIA) concentrates the highest number of international operations with an $87 \%$ of the flights (INECO, 2010).

As mentioned by the International Civil Aviation Organization (ICAO, 2019), studies made with $55 \mathrm{~dB}$ contours of 315 airports worldwide demonstrate that if the aircraft technology and operational improvements implemented in the aircrafts delivered after 2015 are advanced (in a scale of low, moderate, and advanced), it is expected that after 2030 this contour area may no longer expand with the increase of the aircraft traffic. Even though the noise pollution occasioned by the aircraft operations is increasingly reduced with the new technological advances, it is still a phenomenon that needs to be analyzed before the and after construction of the airports so that corrective measures can be taken since the environment is dynamic.

The exposure to aircraft noise has effects in several areas such as human behavior, animal behavior, price of properties, and territorial planning. Noise contour maps enable not only the development of the present scenarios, but also medium and long term plans, testing different track 
orientations and configurations (Sadr et al., 2014). This allows to predict the effects necessary for planning future land use.

The ICAO (2008a) defines in its Doc 9829 Guidance on the Balanced Approach to Aircraft Noise Management four areas that must be considered when a complete analysis of the noise pollution around an airport is performed and before applying any correction that reduces the noise levels. It must consider the reduction of noise at source, the land-use planning and management, the noise abatement operational procedure, and the operating restrictions.

For those decisions, the strategic noise maps, generated from computer models, are the basis for the development of future assessments of the distribution of noise in residential areas and for the preparation of action plans (Probst \& Huber, 2007), which should be of local and global action (Klaeboe, Engelien \& Steinnes, 2006; European Commission Working Group Assessment of Exposure to Noise, 2007). As an example, in the European Union it is mandatory since 2002 that member states evaluate and reduce noise from roads, railways, airports, and urban agglomerations through noise maps use (Garai \& Fattori, 2009).

The Transportation Research Board (2009) mentions that, thanks to maps of noise levels, programs can be developed to modify flight patterns, so they can fly over sites with compatible land uses (especially at low altitude), establish voluntary programs that maximize the use of runway headers that have approach or takeoff patterns more compatible with the land use, or change flights from airports in areas with a high concentration of population to airports in areas with lower population density. In addition, they are a tool to inform the population of existing conditions, so when someone acquires a property or shows interest in it, they cannot claim the right to compensation for damages caused by aeronautical noise (Federal Aviation Administration, 2014).

The Part 150 - Airport Noise Compatibility Planning (Federal Aviation Administration, 2014) is a document that sets the procedures for the development of noise exposure maps as well as ways to determine the exposure to noise that individuals have in terms of air operations. This takes into consideration the land usage present or to be developed in the surrounding area, summarizing in a table the data of which levels of exposure to noise are compatible and obtaining the noise levels of the maps from the noise contours. Airport noise compatibility planning has important effects in urban planning.

Throughout the world, aeronautical noise exposure analysis studies have been developed. In some countries such as Spain, the strategic noise maps are used for evaluating the existing noise exposure around airports. They are also easily available to public access for the main airports and are reviewed every five years (Aena, 2014). In Panama, the noise exposure studies were used to analyze the actual and future effect of the aircraft operations of the Tocumen International Airport noise levels over urbanized and non-urbanized areas (Rodríguez, 2008).

Since noise is a variable that diminishes the quality of life, the analysis of exposed areas by noise contour maps and field data also allows to determine which areas are more critical. For example, Cano (2009) developed maps for the area of influence of the Olaya Herrera International Airport in Colombia using Geographic Information Systems and the sound pressure of 26 points. This 
study allowed to identify the importance of placing at least five fixed sound level meter stations for continuous monitoring of sound pressure levels, which helped the responsibility of the airport administration of maintaining the noise levels within a range considered acceptable for health.

In the case of Costa Rica, the studies conducted in the field of aeronautical noise are scarce, and most of the information is concentrated in the airport master plans. For the JSIA, a noise contours map was created by TAMS Consultants, Inc. (1997), which compares the noise levels of 1995 and those predicted for 2010. The most recent antecedent that is presented in the master plans corresponds to the noise footprints created in 2011 for several locations of the future airport of San Jose (INECO, 2011), including the current location of the JSIA.

The projected operations in the master plan of 2010 elaborated by SH\&E y ICF International Company were adjusted in the present work since the projected operations were higher than the real data from 2011 to 2014. The plan corresponded to a study of 2010 in which the merge of different airlines on a later period as well as the world economic crisis of 2008 severely affected international tourism (Brent, Amaya Molinar \& Frechtling, 2009), influencing the number of flights to and from Costa Rica. This effect was not clearly understood and not incorporated in the study of 2010; hence, an adjustment had to be made.

This study aims to evaluate the noise generated by future aeronautical operations around the Juan Santamaría International Airport and its compatibility with the land use and the proposed zoning around the airport. This work is organized as follows: first the methodology is presented, then results and discussion are shown, and finally, conclusions and recommendations are presented.

\section{METHODOLOGY}

The noise contour maps are used to indicate the amplitude and the magnitude of the impact of noise produced by airplanes around airports (ICAO, 2008b) and are the basis for the development of future assessments of the distribution of noise in residential areas and the preparation of action plans (Probst \& Huber, 2007). Their use should also be of local and global action (Klaeboe, Engelien \& Steinnes, 2006; European Commission Working Group Assessment of Exposure to Noise, 2007). This kind of map includes data of noise contours in decibels and city milestones that allows for geographical location. In addition, it should be considered that the data of the aircraft operations most be composed of 365 days (a year)- register so that the contours will be the result of a yearly day-night average sound level (YDNL).

For this study, the contours were developed using the software BaseOps 7.358 of the developer Wasmer Consulting with backup of the United States Air Force. The software BaseOps 7.358 uses Nmap, which is a Federal Aviation Administration (FAA) approved model for detailed noise analysis (Federal Aviation Administration, 2015). Several authors have used BaseOps for noise modelling, including North Wind (2010), Morris et al. (2011), Christian (2013), and Waiters (2018).

As inputs, data of the aeronautical charts (arrivals, departures, and approaches) included in Costa Rican Aeronautical Information Publication (AIP) and the 2013 data base of the General Civil 
Aviation Authority (DGAC for its name in Spanish) were used, which includes detailed information for each operation such as operating company, type of service, registration and model of the aircraft, flight code, time of arrival, departure time, airport of origin, airport of destination, number of passengers, weight, type of flight (national or international), type of operation (regular or non-regular), day, month, and the exact time of the event. This study does not consider the effect of possible aircraft technology and operational improvements that may be implemented in aircrafts in future years.

Table 1. Distribution of flights by schedule during annual season

\begin{tabular}{ccc}
\hline Schedule & Arrivals & Departures \\
\hline Day & $78,3 \%$ & $82,6 \%$ \\
Evening & $12,6 \%$ & $2,7 \%$ \\
Night & $9,1 \%$ & $14,7 \%$ \\
\hline
\end{tabular}

The operations in the database were classified for the annual season (all year) and distributed according to three variables. First, its schedule (Table 1) with a category that includes the period between 07:00 and 19:00 hours called "day"; another category called "evening" from 19:00 to 22:00 hours, and the period between 22:00 and 07:00 hours for the "night" category. In the case of "night" category, a penalization of $10 \mathrm{~dB}$ over the sound level were applied, which means that for the same event a difference of $10 \mathrm{~dB}$ exists if occurs during the day or evening than if occurs during the night period (General Accounting Office, 2000).

According to ICAO's Recommended Method for Computing Noise Contours around Airports, the day-evening-night average sound level and day-night average sound level measurements are the result of equivalent weighted acoustic levels. The global representation of all the acoustic energies with temporary weighting depends on the time of day (day, evening or night), and arriving to the receiver can be expressed through the formulas (ICAO, 2008b):

$$
\begin{aligned}
& L_{e q, W}=10 * \log \left[t_{0} / T_{0} \sum_{i=1}^{N} g_{i} * 10^{L_{E, i} / 10}\right]+C \\
& g_{i}=10^{\Delta_{i} / 10}
\end{aligned}
$$

where: 
$\mathrm{L}_{\text {eq,W }}$ is the equivalent weighted noise level

$\mathrm{t}_{0}$ is the reference time for the integrated acoustic level

$\mathrm{T}_{0}$ is the time interval

$\mathrm{N}$ are all the all acoustic events

$\mathrm{g}_{\mathrm{i}}$ is the multiplier of the number of flights involved given by (2)

$\mathrm{L}_{\mathrm{Ei}}$ is the level of exposure to noise of an individual event

$\mathrm{C}$ is the constant that can be standardization, seasonal adjustment or other

$\Delta_{\mathrm{i}}$ is the weighting in decibels for period $\mathrm{i}$

Second, each operation was classified by the category of ICAO Doc 8643 Aircraft Type Designers (2012) as shown in Table 2, which considers the category of wake turbulence (H: heavy, M: medium or L: light), the type of aircraft (L: landplane, S: seaplane, A: amphibian, H: helicopter, G: gyrocopter or T: tilt-wing aircraft), the number of engines and its type (P: piston, T: turboprop/ turboshaft, J: jet or E: electric). Finally, the operations were classified according to 13 flight patterns for arrivals and 31 flight patterns for departures identified in the AIP.

Table 2. Distribution of flights by aircraft type during annual season

\begin{tabular}{cc}
\hline Aircraft group & Arrivals and Departures \\
\hline HL2J & $2,7 \%$ \\
HL3J & $0,0 \%$ \\
HL4J & $1,2 \%$ \\
LH1P & $0,1 \%$ \\
LH1T & $0,1 \%$ \\
LH2T & $0,1 \%$ \\
LL1P & $1,1 \%$ \\
LL1T & $23,4 \%$ \\
LL2J & $0,3 \%$ \\
LL2P & $2,1 \%$
\end{tabular}




$\begin{array}{lr}\text { LL2T } & 2,8 \% \\ \text { MH2T } & 0,0 \% \\ \text { ML2J } & 60,9 \% \\ \text { ML2T } & 4,8 \% \\ \text { ML3J } & 0,2 \% \\ \text { ML4J } & 0,0 \% \\ \text { ML4T } & 0,0 \%\end{array}$
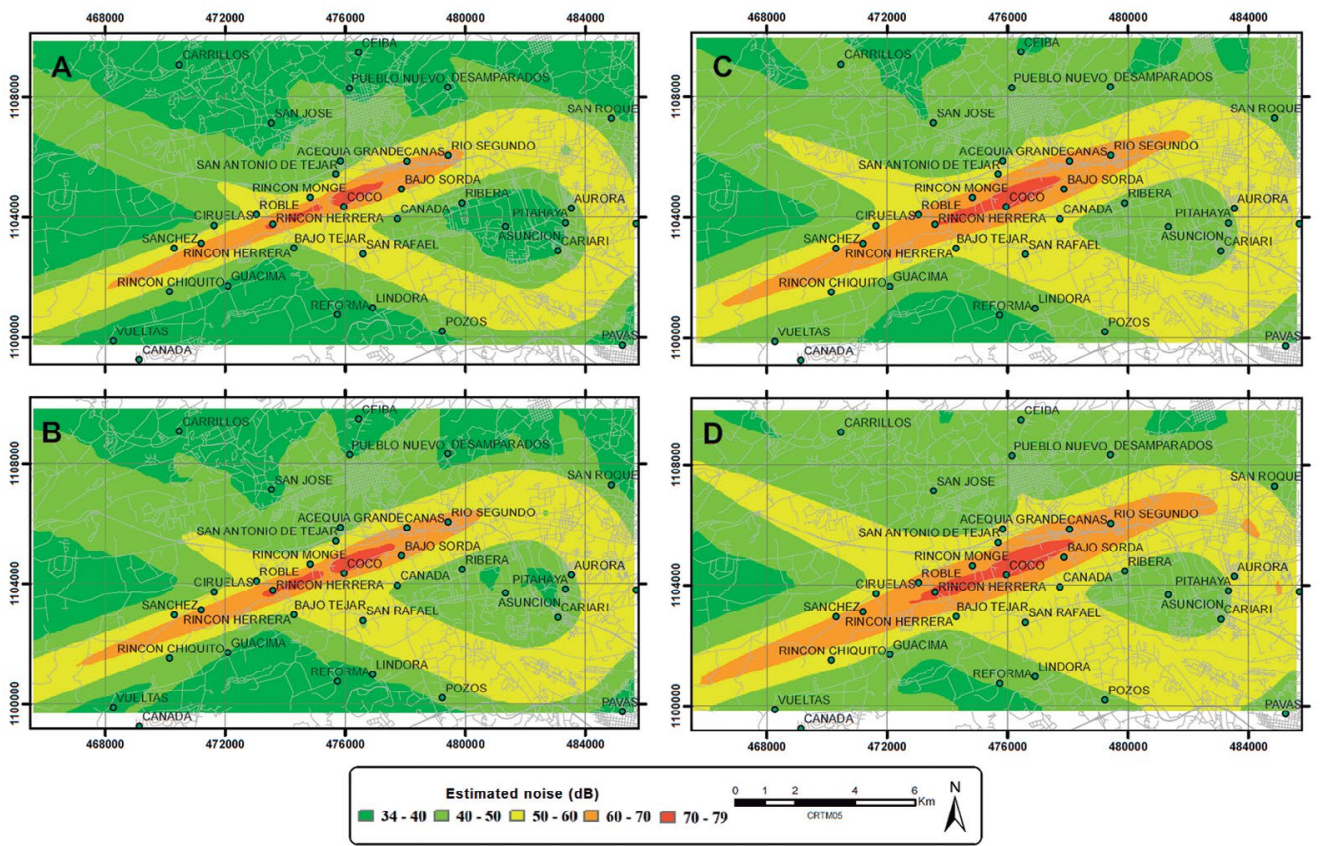

Figure 1. Estimated noise variation during annual season. A) 2013, B) 2016, C) 2026, and D) 2036

To define the number of projected operations in each of the years in study, the data from the Master Plan Update (SH\&E and ICF International Company, 2010) of the Juan Santamaría airport in 2010 was used as a basis, which included methodologies that contemplated three growth rates during the period, a constant growth rate for 19 years and different rate every five years. Then, the data of the master plan between 2002 and 2009 and the real data for the period between 2010 and 2014 were taken, and two new projections were created: one potential and one adjusted potential with a factor that consists of the division between master plan operations (2003 to 2009), real data (2010 to 2014), and operations calculated with the potential projection (2003 to 2014) in order to 
avoid overestimating the actual operations as a result of starting the potential projection at 2003. Finally, a review was made of all projections to determine the minimum, average, and maximum rate for each of the years between 2014 and 2029. Then, this was projected for each year based on each average rate, starting from the real operations in 2014 (76 343) and continuing from 2030 to 2036 with the rate of 2029 at a constant rate. From the previous analysis, it was obtained that the projected operations for the three years of analysis of study are 82659 in 2016, 113533 in 2026, and 149097 in 2036.

With the indicated data, four scenarios were modeled for the annual estimate years: 2013 (data base), 2016, 2026, and 2036. With the information of the noise contours every $1 \mathrm{~dB}$, the theoretical distribution of the models was obtained for each scenario drawing ranges of $10 \mathrm{~dB}$ between the minimum and maximum values. Figure 1 graphically shows the variation of the noise level for the annual season within the analysis period (2013 to 2036).

\section{RESULTS}

\subsection{Computational models}

Based on the models defined for each annual season (2013, 2016, 2026, and 2036), which does not consider the effect of possible aircraft technology and operational improvements that may be implemented in the aircrafts during the future years, it was determined some parameters that reflect on how the noise pollution changed from one season to the other. Table 3 includes a comparison for the seasons 2016, 2026, and 2036 with the 2013, so the average increase in decibels and the percentage increase of the clearly perceivable ( $5 \mathrm{~dB}$ to $10 \mathrm{~dB})$ and double loudness (10 $\mathrm{dB}$ to $14 \mathrm{~dB}$ ) areas can be observed. This analysis was performed to determine how perceptible the sound variations could be between years of analysis in the studied area. The ranges of variations (Araya, 2002) of $+5 \mathrm{~dB}$ (clearly perceivable) and $+10 \mathrm{~dB}$ (double loudness) were taken as reference parameters, and comparisons were made with respect to 2013 and to the annual season, overlaying the maps of the four created scenarios.

Table 3. Summary of estimated changes between seasons

\begin{tabular}{cccc}
\hline & \multicolumn{3}{c}{ Season } \\
Changes compared with 2013 annual season data & & 2026 & 2036 \\
\hline Average increase $(\mathrm{dB})$ & 2016 & +4.37 & +6.05 \\
Clearly perceivable $(5 \mathrm{~dB}$ to $10 \mathrm{~dB})$ areas $(\%)$ & +0.20 & +13.81 & +41.24 \\
Double loudness $(10 \mathrm{~dB}$ to $14 \mathrm{~dB})$ areas $(\%)$ & +0.00 & +0.59 & +1.36 \\
\hline
\end{tabular}


Comparing the estimation between the years, the average increase between 2013 and 2016 is 1,69 dB, between 2013 and 2026 round to a total of 4,37 dB (+2,68 dB from 2016), and for 2036 the increase is $6,05 \mathrm{~dB}$ compared to 2013 (+1,68 dB compared to 2026). Comparing 2026 data of how perceptible the sound variations could be with 2013 data, the clear perceivable areas ( $5 \mathrm{~dB}$ to $10 \mathrm{~dB}$ ) cover a 13,81\% whereas the increases in clear perceivable areas (5 dB to $10 \mathrm{~dB})$ for 2036 reaches a $41,24 \%$. For double loudness areas $(10 \mathrm{~dB}$ to $14 \mathrm{~dB})$, these are practically negligible up to 2026 , being a $1,36 \%$ for 2036 and equivalent to $2,74 \mathrm{~km}^{2}$. While analyzing the most critical scenario (annual 2036), it was intended to determine geographically (Figure 2) which places could require special attention within the 20 years of the projection period regarding the estimated conditions of 2016 as base. This could be obtained by defining as areas of special attention those with clear perceivable increases $(5 \mathrm{~dB}$ to $10 \mathrm{~dB})$ and those with double loudness (10 dB to $14 \mathrm{~dB})$.

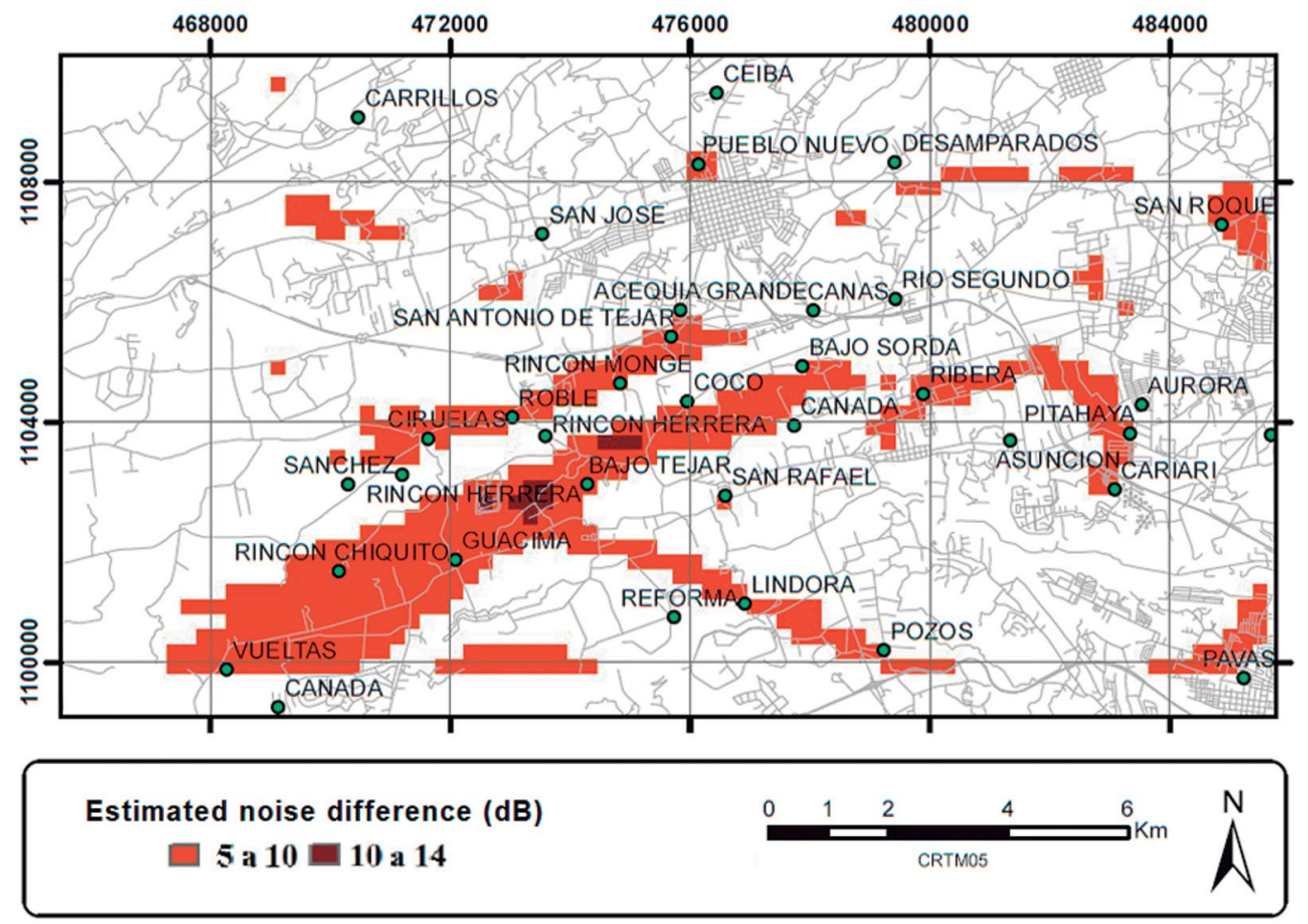

Figure 2. Most critical areas for changes between 2016 annual season and 2036 annual season

For 2036 in comparison with 2016, it is projected that the special attention areas will cover 14,49 $\%$ of the study area, being 14,20\% part of the clear perceivable range ( $5 \mathrm{~dB}$ to $10 \mathrm{~dB}$ ) and located mainly around the towns of San Antonio del Tejar, Roble, Ciruelas, Rincón Chiquito, Bajo Tejar, Lindora, Pozos, Coco, Bajo Sorda, Ribera, Pueblo Nuevo, Vueltas, Pavas, San Rafael, Pitahaya, Cariari, Rincón de Monge, and San Roque.

The limitations stated by the Part 150 of the FAA are compared with the land use in Figure 3. This Figure shows the noise contours between $65 \mathrm{~dB}$ and $85 \mathrm{~dB}$ and the corresponding map of land uses. Similarly, Figure 4 compares the noise contours of 2036 against the zoning established in the 
proposed regulatory plan for the area. Table 4 summarizes how the area affected by $65 \mathrm{~dB}$ or more is distributed depending on each type of zoning and the noise projections for 2036.

Table 4. Surface by zoning according to the estimated noise for the 2036 annual season*

\begin{tabular}{|c|c|c|c|c|c|c|c|c|}
\hline \multirow{2}{*}{ Zoning/ Surface } & \multicolumn{2}{|c|}{$(65$ to 70$) \mathrm{dB}$} & \multicolumn{2}{|c|}{$(70$ to 75$) \mathrm{dB}$} & \multicolumn{2}{|c|}{$(75$ to 80$) \mathrm{dB}$} & \multicolumn{2}{|c|}{ (80 to 83$) \mathrm{dB}$} \\
\hline & $\left(\mathrm{km}^{2}\right)$ & $\%$ & $\left(\mathrm{~km}^{2}\right)$ & $\%$ & $\left(\mathrm{~km}^{2}\right)$ & $\%$ & $\left(\mathrm{~km}^{2}\right)$ & $\%$ \\
\hline Consolidated nucleus & 0,13 & $2 \%$ & 0,01 & $0 \%$ & - & $0 \%$ & - & $0 \%$ \\
\hline Unconsolidated nucleus & 0,19 & $3 \%$ & 0,19 & $3 \%$ & 0,02 & $0 \%$ & - & $0 \%$ \\
\hline Expansion & 1,10 & $17 \%$ & 0,27 & $4 \%$ & - & $0 \%$ & - & $0 \%$ \\
\hline Urban restriction & 0,28 & $4 \%$ & 0,05 & $1 \%$ & - & $0 \%$ & - & $0 \%$ \\
\hline $\begin{array}{c}\text { Logistics services, offices and } \\
\text { warehouses }\end{array}$ & 0,61 & $9 \%$ & 0,48 & $7 \%$ & 0,06 & $1 \%$ & - & $0 \%$ \\
\hline $\begin{array}{c}\text { Commerce, logistics services, } \\
\text { offices, warehouse }\end{array}$ & 0,24 & $4 \%$ & - & $0 \%$ & - & $0 \%$ & - & $0 \%$ \\
\hline Commercial & 0,08 & $1 \%$ & - & $0 \%$ & - & $0 \%$ & - & $0 \%$ \\
\hline Agricultural & 0,90 & $14 \%$ & 0,44 & $7 \%$ & 0,11 & $2 \%$ & - & $0 \%$ \\
\hline Airport & 0,28 & $4 \%$ & 0,78 & $12 \%$ & 0,33 & $5 \%$ & 0,05 & $1 \%$ \\
\hline TOTAL & 3,82 & $58 \%$ & 2,22 & $34 \%$ & 0,52 & $8 \%$ & 0,05 & $1 \%$ \\
\hline
\end{tabular}

*Areas smaller than $1000 \mathrm{~m}^{2}$ are not shown

Comparing the 2016 conditions against the Part 150 of the FAA limits, it is recommended to incorporate solutions in the construction regulations to reduce between $25 \mathrm{~dB}$ and $30 \mathrm{~dB}$ in the residential areas and schools located within the range of $65 \mathrm{~dB}$ to $70 \mathrm{~dB}$. In this case, it refers to the vicinity of the airport, Coco, southeast of Rincón de Monge, Rincón de Herrera (nearby El Roble and Ciruelas), and Bajo Sorda. For hospitals, nursing homes, churches, auditoriums, and concert halls within these same neighborhoods, they must incorporate solutions that reduce $25 \mathrm{~dB}$.

For the areas near the airport such as El Coco, southeast of Rincón de Monge, and Rincón de Herrera (near El Roble) located within the range of $70 \mathrm{~dB}$ to $75 \mathrm{~dB}$, the noise level reduction (NLR) 
should be increased to $30 \mathrm{~dB}$ in hospitals, nursing homes, churches, auditoriums, and concert halls. In addition, $25 \mathrm{~dB}$ of NLR are required for governmental services and buildings where the public is received and office areas located near transportation and parking land use. The most critical case, the west runway (near Coco) within a range of $75 \mathrm{~dB}$ to $80 \mathrm{~dB}$, is not compatible with the uses for residential, schools, hospitals, nursing homes, churches, auditoriums, and concert halls. In addition, the reduction requested should increase to $30 \mathrm{~dB}$ for governmental services and buildings where the public is received and office areas located near transportation and parking land use.

Analyzing the 2036 contour map with the zoning map, the agricultural areas near Cañas are in the range of $65 \mathrm{~dB}$ to $70 \mathrm{~dB}$ while the areas west of Bajo Sorda, east of Rincón de Herrera (near Ciruelas), and south of Rincon de Monge are also in the range of $70 \mathrm{~dB}$ to $75 \mathrm{~dB}$, representing $1,34 \mathrm{~km}^{2}$. In both ranges, the usage for agriculture, forestry, livestock farming and breeding are compatible, but if residential buildings in the range of $65 \mathrm{~dB}$ to $70 \mathrm{~dB}$ are built, the construction regulations should include NLR of $25 \mathrm{~dB}$ and $30 \mathrm{~dB}$ if the range is $70 \mathrm{~dB}$ to $75 \mathrm{~dB}$. For the 0,11 $\mathrm{km}^{2}$ within the range of $75 \mathrm{~dB}$ to $80 \mathrm{~dB}$, south of Rincón de Monge, residential building, livestock farming and breeding are not allowed while agriculture and forestry are permitted.

The areas of logistics services, offices, and warehouses (equivalent to the land use of offices, businesses, and professional of the Part 150 of the FAA) nearby Bajo Sorda and Rincón de Monge includes ranges of $65 \mathrm{~dB}$ to $70 \mathrm{~dB}$ and $70 \mathrm{~dB}$ to $75 \mathrm{~dB}$ while for the vicinity of Coco the variation is between $65 \mathrm{~dB}$ and $80 \mathrm{~dB}$, including three ranges. For areas between $65 \mathrm{~dB}$ and $70 \mathrm{~dB}(0,61$ $\mathrm{km}^{2}$ ), the land use is compatible without restrictions; however, when the range increases to $70 \mathrm{~dB}$ to $75 \mathrm{~dB}\left(0,48 \mathrm{~km}^{2}\right)$, measures that reduce $25 \mathrm{~dB}$ must be incorporated into the design or construction stages of buildings, and for the $0,06 \mathrm{~km}^{2}$ in the vicinity of Coco ( $75 \mathrm{~dB}$ to $\left.80 \mathrm{~dB}\right)$, it will be required a NLR of even $30 \mathrm{~dB}$.

For the commercial areas north of Guácima and south of El Roble and the commerce, logistics services, offices, and warehouse areas between Cañas and Río Segundo are projected to be in the range of $65 \mathrm{~dB}$ to $70 \mathrm{~dB}$, representing a $0,32 \mathrm{~km}^{2}$ and implying that the land use of offices, business, professional, wholesale and retail (building materials, hardware, and farm equipment), retail trade (general), utilities, and communication can continue developing without restrictions.

With the expansion urban areas, the land uses are defined and could be developed for 2036 conditions. For the $1,10 \mathrm{~km}^{2}$, areas within the range of $65 \mathrm{~dB}$ to $70 \mathrm{~dB}$ (south of the airport, nearby Rincón de Herrera by Ciruelas and south Sánchez) should be limited to governmental services, transportation and parking. Hospitals, nursing homes, churches, auditoriums, and concert halls are compatible if they incorporate in the design measures NLR of $25 \mathrm{~dB}$. For the $0,27 \mathrm{~km}^{2}$ between $70 \mathrm{~dB}$ and $75 \mathrm{~dB}$ south of El Roble, compatible uses are the same as in the previous range but with NLR of $30 \mathrm{~dB}$ in hospitals, nursing homes, churches, auditoriums, and concert halls, of $25 \mathrm{~dB}$ in governmental services, and $25 \mathrm{~dB}$ in the office areas located near transportation and parking land use.

Finally, with the consolidated nucleus of Río Segundo and Rincón de Herrera (near Ciruelas) and the unconsolidated nucleus in Coco where the range is $65 \mathrm{~dB}$ to $70 \mathrm{~dB}$ and the one south of El Roble where the ranges of $65 \mathrm{~dB}$ to $70 \mathrm{~dB}$ and $70 \mathrm{~dB}$ to $75 \mathrm{~dB}$ are present (representing a total of 
$0,52 \mathrm{~km}^{2}$ ), the residential areas are not compatible; nevertheless, when the community determines that residential or school areas must be allowed, constructions regulations must include NLR between $25 \mathrm{~dB}$ and $30 \mathrm{~dB}$. For the $0,02 \mathrm{~km}^{2}$ of unconsolidated nucleus in Rincón de Herrera (near El Roble), the noise level range is of $75 \mathrm{~dB}$ to $80 \mathrm{~dB}$, which under no circumstances residential buildings should exist; however, as showed on Figure 3, this is already an area of urban use.

Summarizing the considerations established with the computational models and the criteria of compatibility according to the DNL, the most critical areas for territorial planning are the urban zones of Coco and the south of Rincón de Monge, which require incorporating constructive measures that reduce in $25 \mathrm{~dB}$ to $30 \mathrm{~dB}$ the noise levels produced by aircrafts and even ban new residential and public use buildings in the areas of sound ranges from $75 \mathrm{~dB}$ to $80 \mathrm{~dB}$. Moreover, a small area of Rincón de Herrera (near El Roble) is in the $75 \mathrm{~dB}$ to $80 \mathrm{~dB}$ range, but it is already urbanized and the possibilities to incorporate constructive solutions that reduce the perceived sound level of the aircraft are less.

The other critical areas are logistics services, offices, and warehouses nearby of Bajo Sorda and Rincón de Monge where NLR of $25 \mathrm{~dB}$ could be required and those near Coco with $30 \mathrm{~dB}$ of NLR. The nucleus in Río Segundo and Rincón de Herrera (near Ciruelas) also required these critical areas where the new constructive permits must be granted only with the analysis of specific cases and approved noise mitigation measures.

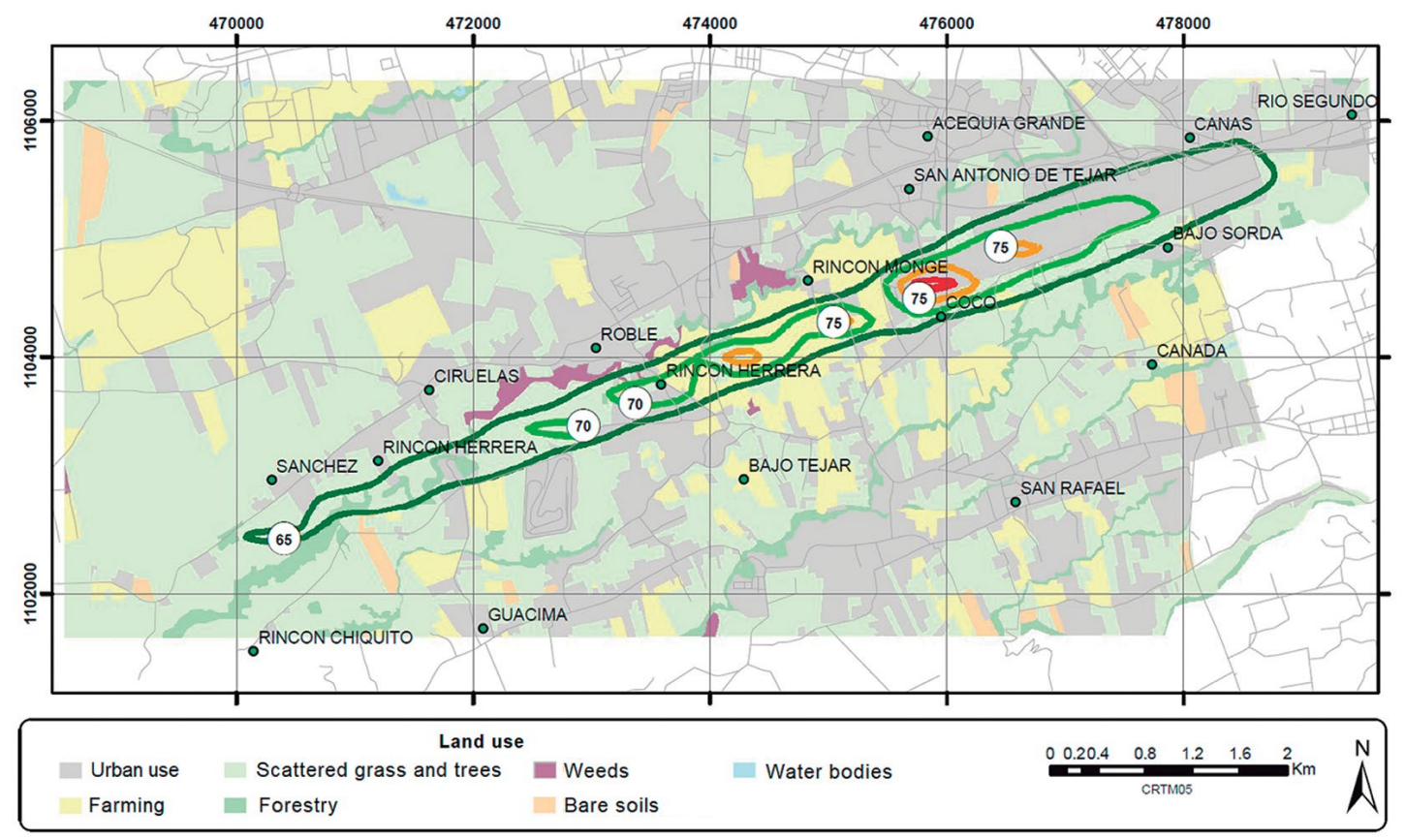

Figure 3. 2016 annual season noise contours and land use nearby JSIA Source: Civil Engineer School - Sustainable Urban Development Research Program, (2017) 


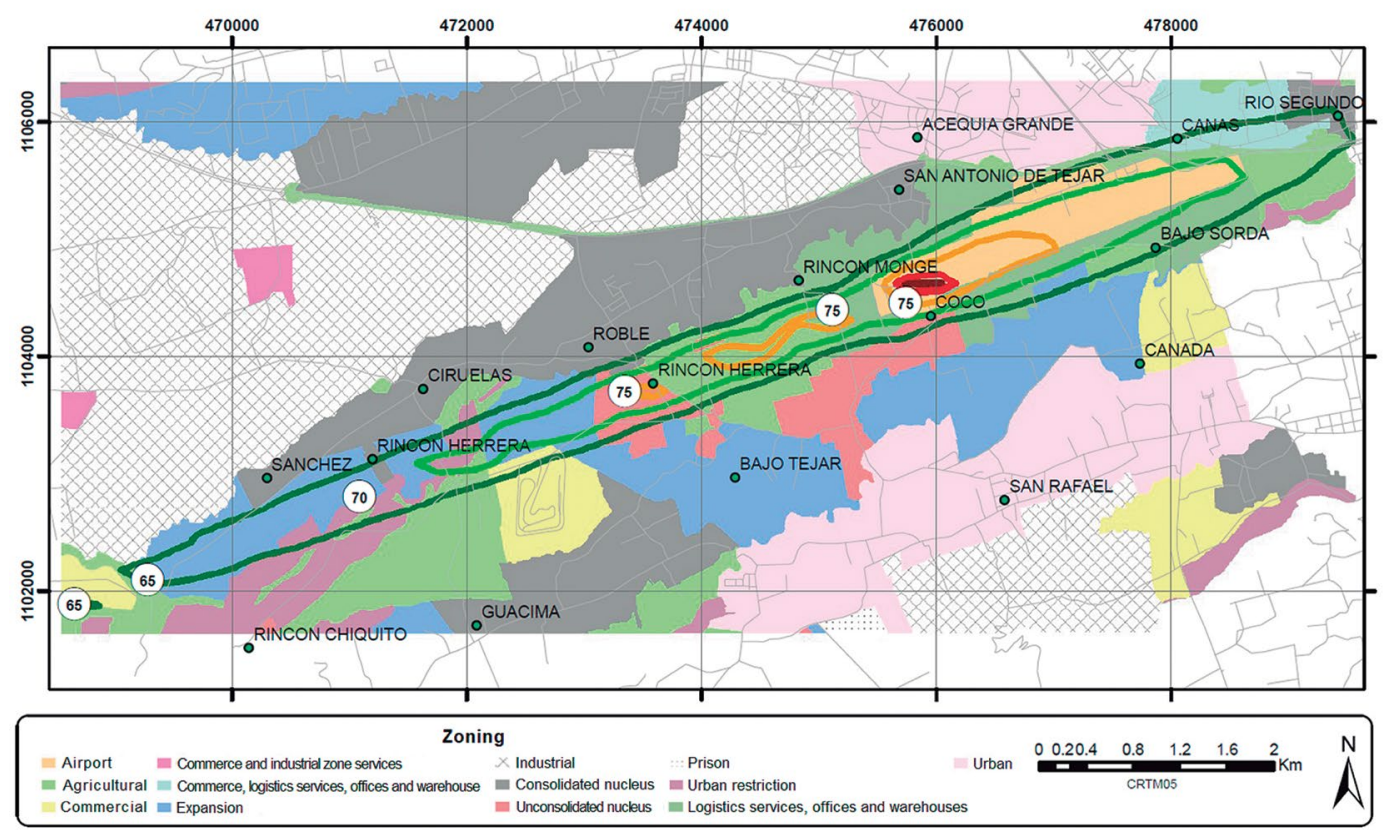

Figure 4. 2036 annual season noise contours and zoning nearby JSIA Source: Civil Engineer School - Sustainable Urban Development Research Program, (2017)

\subsection{Sound level measurements}

For the field measurements, 28 points were selected in which 20 of them were based in the studies Sonic Pollution Impact in the Neighborhood of the International Airport Juan Santamaria, Costa Rica by Vargas, Álvarez and Asch in 1996 and Evaluation of the sonic contamination produced by airplanes in the areas surrounding the Juan Santamaría Airport by Álvarez in 1999. The remaining eight points were selected for extending the measurements in areas further away from the airport with four of them to the north and four to the south since the 20 points were located near it. The sound level meter used was an Extech Instruments model 407750 with a range of $30 \mathrm{~dB}$ to $130 \mathrm{~dB}$ and an accuracy of $\pm 1,5 \mathrm{~dB}$ (FLIR Commercial Systems Inc, 2013), which collects information every second in a recording system. It meets the American National Standards Institute (ANSI) and International Electrotechnical Commission (IEC) Type 2 standards of the "ANSI S1 .4: Specifications for Sound Level Meters", which is the minimum requirement by the Occupational Safety and Health Administration (OSHA) for noise measurements and is usually sufficient for general purpose noise surveys (Occupational Safety \& Health Training, n.d.).

The measurements were at different times mainly between 10:12 and 17:24 with some additional records at certain points between 18:30 and 21:15. The length of the measurement at each point varied between 11 and 59 minutes with the objective of registering at least three aircraft operations per point where each operation was measured during periods of five seconds. For the measurement points, a verification was made of how much the sound level of the environment varied with aircraft operations. For them, differentials were estimated between average environmental noise and average aircrafts noise, finding out that the variation was between $-2,1 \mathrm{~dB}$ and 19,5 $\mathrm{dB}$. These differences 
were classified in Figure 5 with the categories of how perceptible a variation in a sound can be for humans where $\pm 3 \mathrm{~dB}$ are barely perceptible outside of laboratory conditions, $\pm 5 \mathrm{~dB}$ are clearly perceivable, and $\pm 10 \mathrm{~dB}$ are of doubled or half loudness.

Only one of the 28 points shows a decrease in the sound level, and the increase cannot be considered as perceivable in four of them; however, in $57 \%$ of the measurements (16 points), the increase in sound level can be cataloged as clearly perceivable ( $5 \mathrm{~dB}$ to $10 \mathrm{~dB}$ ) while the other 25 $\%$ (seven points) were of doubled loudness (10 dB to $14 \mathrm{~dB})$. From the measure points, the seven with doubled loudness (10 $\mathrm{dB}$ to $14 \mathrm{~dB})$ are located mainly near the airport's runway and towns of Río Segundo and Aurora. From the 16 points with a clear perceivable increase ( $5 \mathrm{~dB}$ to $10 \mathrm{~dB}$ ), some of these are located near towns where the modeling determined increased sound conditions such as in San Antonio del Tejar, Asunción, Ciruelas, Roble, Desamparados, Bajo Tejar, Coco, Cañada, and Ribera.

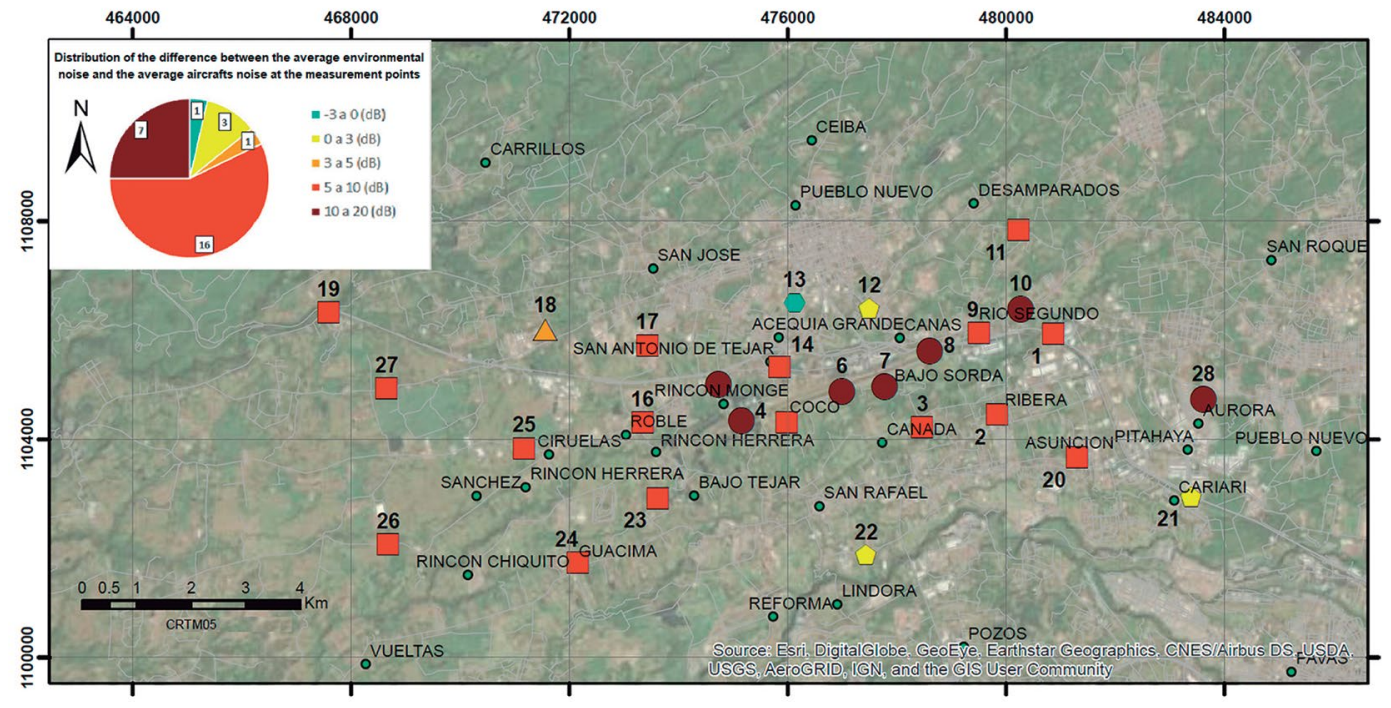

Figure 5. Distribution of the difference between the average environmental noise and the average aircrafts noise at the measurement points

From the results of the field data collection, it can be considered that the most critical areas for development and territorial planning would be point eight (industrial area) located near Río Segundo, the points in urban-residential areas which are number four near Rincón de Monge, number five near Coco, six and seven near Bajo Sorda, ten in Río Segundo, 14 in San Antonio de Tejar, and 28 in Aurora.

\section{DISCUSSION AND CONCLUSIONS}

From 2016 to 2036, the increase for the annual average noise in clear perceivable areas ( $5 \mathrm{~dB}$ to $10 \mathrm{~dB})$ reaches over a $40 \%$ of the area and for double loudness areas (10 $\mathrm{dB}$ to $14 \mathrm{~dB})$ reaches a $1,36 \%$ for 2036 which is equivalent to $2,74 \mathrm{~km}^{2}$. It is necessary to control the future growth of zones with urban, logistics, offices, and warehouses land use in the nearby of the JSIA to mitigate the noise effects that future operations can produce. It is necessary to focus the efforts for planning 
and limiting into the expansion zones and unconsolidated nucleus named in the Alajuela's Regulatory Plan, which represent around 1,77 km². The construction of new homes, schools, hospitals, nursing homes, churches, auditoriums, and concert halls must be banned in zones within $75 \mathrm{~dB}$ and $80 \mathrm{~dB}$, a measure which can be incorporated into the proposed zonings of the new Regulatory Plan. Areas nearby El Coco, Rincón de Monge, El Roble, Rincón de Herrera, Sánchez, and Bajo Sorda require special attention because the sound level in these areas is incompatible with residential land use according to the noise maps and the sound level measurements.

The noise generated by the aircrafts operations during the night period could be a problem in the urban and residential areas nearby the JSIA; hence, the compatibility between the location of the urban and residential areas and the number of aeronautical operations that takes place during the night period must be evaluated. It should be considered if it is necessary to modify the routes used by the aircrafts during night. Even though the scope of this study focus only in the analysis of alternatives that can reduce the aircraft noise pollution based on land use planning and management solutions, it is important to consider also the reduction of noise at source, the noise abatement operational procedures, and the operating restrictions for executing an integral solution as it is recommended in the ICAO's Guidance on the Balanced Approach to Aircraft Noise Management.

Aircrafts noise is just one source of the sound pollution in the area, which is a reason why a sound level research for other means of transportation that operate in the area of study (for example vehicles on the General Cañas Road nearby the airport) must be carried out, and the results must be compared for an integral analysis of the territorial planning. Moreover, it must be considered a comparison of the showed results with a sensitive analysis over variables such as total number of aircraft operations projected, type of aircrafts, hours of the operations, and distribution of the operations between all the available tracks of departure and arrival.

\section{REFERENCIAS}

Aena S.A. (2014). Mapas estratégicos de ruido [Strategic noise maps]. Retrieved from http://www.aena.es/es/corporativa/ mapas-estrategicos-ruido.html

Álvarez, J. (1999). Evaluación de la contaminación sónica producida por los aviones en las áreas aledañas al Aeropuerto Juan Santamaría [Evaluation of noise pollution produced by airplanes in the areas surrounding the Juan Santamaría Airport]: A thesis in physical geography (Bachelor's degree Thesis). Heredia: Costa Rica National University

Araya, J. (2002). Contaminación sónica y su control [Noise pollution and its control]. San Jose: CICIMA \& Physics School, University of Costa Rica.

Berglund, B., Lindvall, T. \& Schwela, D.H. (1999). Guidelines for community noise. Geneva: World Health Organization. Retrieved from http://whqlibdoc.who.int/hq/1999/a68672.pdf

Black, D.A., Black, J.A., Issarayangyun, T. \& Samuels, S.E. (2007). Aircraft noise exposure and resident's stress and hypertension: A public health perspective for airport environmental management. Journal of Air Transport Management, 13(5), 264-276. Retrieved from https://doi.org/10.1016/j.jairtraman.2007.04.003

Brent Richie, J.R., Amaya Molinar, C. \& Frechtling, D.C. (2009). Impacts of the World Recession and Economic Crisis on Tourism: North America. Journal of Travel Research, 49(1), 5-15. Retrieved from https://doi. org/10.1177/0047287509353193 
Cano, J. (2009). Metodología para el análisis de la dispersión del ruido en aeropuertos, estudio de caso: Aeropuerto Olaya Herrera de la ciudad de Medellín [Methodology for the analysis of noise dispersion in airports, case study: Olaya Herrera Airport in the city of Medellin]: Environment and development master's program (Master's thesis). Medellín: Colombia National University.

Christian, A. W. (2013). A multi-objective evolutionary optimization approach to procedural noise mitigation for nearground aircraft (Master of Science Thesis in Acoustics). USA: Pennsylvania State University.

Civil Engineer School - Sustainable Urban Development Research Program. (2017). Zoning map and land use map of the Alajuela's Regulatory Plan. San Jose, Costa Rica: University of Costa Rica.

Dekkers, J.E.C. \& van der Straaten, J.W. (2009). Monetary valuation of aircraft noise: A hedonic analysis around Amsterdam airport. Ecological Economics, 68(11), 2850-2858. Retrieved from https://doi.org/10.1016/j. ecolecon.2009.06.002

Eagan, M.E.(2007, Mayo). Using Supplemental Metrics to Communicate Aircraft Noise Effects. Ponencia presentada en el Noise-Con 2006. Burlington, Massachusetts: Harris Miller Miller \& Hanson Inc.

European Commission Working Group Assessment of Exposure to Noise (WG-AEN). (2007). Good Practice Guide for Strategic Noise Mapping and the Production of Associated Data on Noise Exposure v.2. Retrieved from https://www.lfu.bayern.de/laerm/eg_umgebungslaermrichtlinie/doc/good_practice_guide_2007.pdf

Federal Aviation Administration. (2014). Part 150 - Airport Noise Compatibility Planning. Retrieved December 20, 2019 from http://www.ecfr.gov/cgi-bin/text-idx?c=ecfr\&sid=44fb7ed6bee65430ad245a9c5ae4 $9582 \&$ rgn $=$ div $5 \&$ view $=$ text $\&$ node $=14: 3 \cdot 0 \cdot 1 \cdot 3 \cdot 21 \&$ idno $=14$

Federal Aviation Administration. (2015). 1050.1F Desk Reference, Retrieved from https://www.faa.gov/about/office_org/ headquarters_offices/apl/environ_policy_guidance/policy/faa_nepa_order/desk_ref/.

FLIR Commercial Systems Inc. (2013). Extech Instruments Digital Sound Level Meter Model 407750 User's Guide. Retrieved from http://translate.extech.com/instruments/resources/manuals/407750_UM-en.pdf

Garai, M. \& Fattori, D. (2009). Strategic noise mapping of the agglomeration of Bologna, Italy. Urban Transport XV. Urban Transport and the Environment, 519-528. Retrieved from http://acustica.ing.unibo.it/Researches/ noisemapping/index.html

General Accounting Office (GAO). (2000). Aviation and the Environment FAA's Role in Major Airport Noise Programs. (Report to Congressional Requesters GAO/RCED-00-98) Washington, D.C.: United States General Accounting Office.

Hsu, C. \& Lin, P. (2005). Performance assessment for airport noise charge policies and airline network adjustment response. Transportation Research Part D: Transport and Environment, 10(4), 281-304. Retrieved from https:// doi.org/10.1016/j.trd.2005.04.009

INECO (2010). Comprehensive plan for modernization of network of airports in Costa Rica. Report R9 Version for client review. Informe Final. San Jose, Costa Rica.

INECO (2011). Estudio de emplazamiento del futuro aeropuerto de San José [Location study for the San Jose's future airport]. San Jose, Costa Rica.

International Civil Aviation Organization (ICAO). (2008a). Guidance on the Balanced Approach to Aircraft Noise Management (2nd Edition). Montreal, Quebec, Canada.

International Civil Aviation Organization (ICAO). (2008b). Recommended Method For Computing Noise Contorus Around Airports (1st Edition). Montreal, Quebec, Canada.

International Civil Aviation Organization (ICAO). (2012). Aircraft Type Designators (40th Edition). Montreal, Quebec, Canadá.

International Civil Aviation Organization (ICAO). (2019). Global trends in Aircraft Noise. Retrieved from protection/ Pages/Noise_Trends.aspx

Klaeboe, R., Engelien, E. \&y Steinnes, M. (2006). Context sensitive noise impact mapping. Applied Acoustics, 67(7), 620-642. Retrieved from https://doi.org/10.1016/j.apacoust.2005.12.002 
Ministry of Public Works and Transportation from Costa Rica- General Civil Aviation Authority (2014). Aeronautical Information Publication (AIP). San Jose, Costa Rica.

Morris, P. J., McLaughlin, D., Sparrow, V., Bridges, J., Henderson, B., Plotkin, K., \& McKinley, R. (2011). The Reduction of Advanced Military Aircraft Noise (No. WP-1583). Pennsylvania: State University State College.

North Wind. (2010). Final Environmental Assessment For the Expansion and Relocation of the Explosive Ordnance Disposal Preliminary Course to Sheppard Air Force Base, Texas. Prepared for Air Education Training Command (AETC) Randolph AFB, Texas and The Air Force Center for Engineering and the Environment (AFCEE), USA.

Occupational Safety \& Health Training. (n.d.). Course 751 Hearing Conservation Program Management - Considerations of use for sound level meters. Retrieved from https://www.oshatrain.org/courses/mods/751_Considerations_ Sound_Level_Meter.html

Probst, W. and Huber, B. (2007). How to evaluate the accuracy of noise mapping calculations - the standardized approach according to DIN 45687. Paper presented during the INTER-NOISE 2007. Estambul, Turquía.

Püschel, R. and Evangelinos, C. (2012). Evaluating noise annoyance cost recovery at Düsseldorf International Airport. Transportation Research Part D, 18(8), 598-604. Retrieved from https://doi.org/10.1016/j.trd.2012.07.002

Rodríguez, E. (2008). Aspectos e impactos ambientales de construcción y ampliación de la operación y el funcionamiento del Aeropuerto Internacional de Tocumen en la República de Panamá [Aspects and environmental impacts of construction and expansion of the operation of the Tocumen International Airport in the Republic of Panama]: Environmental science program (Master's thesis). Ciudad de Panamá: Technological University of Panama.

Sadr, M.K., Nassiri, P., Hosseini, M., Monavari, M. \& Gharagozlou, A. (2014). Assessment of land use compatibility and noise pollution at Imam Khomeini International Airport. Journal of Air Transport Management, 34, 49-56. Retrieved from https://doi.org/10.1016/j.jairtraman.2013.07.009

SH\&E \& ICF International Company (2010). Actualización del Plan Maestro: documentos de soporte [Master Plan Update: supporting documents]. San Jose, Costa Rica.

TAMS Consultants, Inc. (1997). Estudio de modernización y ampliación del Aeropuerto Internacional Juan Santamaría y selección de sitio para un nuevo aeropuerto [Study of modernization and expansion of Juan Santamaría International Airport and site selection for a new airport]. Final Report Volume II. San Jose, Costa Rica.

Transportation Research Board. (2008). ACRP Synthesis 9: Effects of Aircraft Noise: Research Update on Select Topics. Washington, DC: The National Academies Press. Retrieved from https://doi.org/10.17226/14177

Transportation Research Board. (2009). ACRP Report 15 - Aircraft Noise: A Toolkit for Managing Community Expectations. Washington, DC: The National Academies Press. Retrieved from https://doi.org/10.17226/14338

Vargas, M., Álvarez, J. \& Asch, C. (1996). Sonic Pollution Impact in the Neighborhood of the International Airport Juan Santamaria, Costa Rica. Paper presented during World Congress Air Pollution in Developing Countries. San Jose, Costa Rica

Waiters, A. L. (2018). Land Cover Influences on Airborne Noise Propagation at USAF Installations (Master of Science in Environmental Engineering Thesis). Air Force Institute of Technology, USA.

Wasmer, F. \& Maunsell, F. (n.d.). BaseOps 7.358 User's Guide. United States. Retrieved from https://wasmerconsulting. com/baseops_build1403/baseops_users_guide.pdf

World Health Organization (WHO). (2009). Night Noise Guidelines for Europe. Copenhagen, Denmark: WHO Regional Office for Europe. Retrieved from http://www.euro.who.int/_data/assets/pdf_file/0017/43316/E92845.pdf

$\mathrm{Xie}, \mathrm{H} ., \mathrm{Li}, \mathrm{H}$. \& Kang, J. (2014). The characteristics and control strategies of aircraft noise in China. Applied Acoustics, 84, 47-57. Retrieved from https://doi.org/10.1016/j.apacoust.2014.01.011 